\title{
PEMBERDAYAAN MASYARAKAT PETANI DALAM MENINGKATKAN KESEJAHTERAAN HIDUP DI KECAMATAN COMPRENG KABUPATEN SUBANG
}

\author{
Asep Bambang Iryana \\ Bepe.a20@gmail.com
}

\author{
Dosen Jurusan Ilmu Pemerintahan STIP-AN
}

\begin{abstract}
Abstrak
Keberadaan Paguyuban Petani Kecamatan Compreng GAPOKTAN (Gabungan Kelompok Tani) dilatarbelakangi oleh keinginan yang kuat untuk membebaskan diri dari kemiskinan. Kemiskinan petani tersebut menandai betapa lemah posisi tawar petani terhadap struktur politik, ekonomi, sosial, dan budaya yang ada. Pergulatan sejarah di negeri ini telah menempatkan petani dalam posisi marginal sedangkan yang harusnya petani, sebagai penyangga pilar kehidupan, tidak boleh terabaikan. Maksud dan Tujuan penelitian ini meliputi (1) Melakukan kajian terkait pemberdayaan masyarakat petani di Kecamatan Compreng Kabupaten Subang (2) Tersedianya data dan informasi serta referensi dalam upaya penyelenggaraan pemerintahan dengan konsep terbaru.
\end{abstract}

Teknik pengumpulan data, yaitu: observasi, wawancara, dan dokumentasi. Teknik keabsaan data yang digunakan dalam penelitian ini yaitu triangulasi sumber dan triangulasi metode. Teknik analisis data yang digunakan dalam penelitian ini yaitu teknik analisis data kualitatif, yaitu pengumpulan data, reduksi data, penyajian data, dan penarikan kesimpulan/verifikasi.

Berdasarkan hasil penelitian didapatkan hasil bahwa Keberadaan GAPOKTAN di Kecamatan Compreng sangat membantu sekali untuk keberlangsungan kesejahteraan hidup para petani oleh karenanya pemerintah harus mampu mengelola dengan baik keberadaan GAPOKTAN. Pemerintah memiliki peran penting dalam melakukan pemberdayaan masyarakat karena bertanggung jawab atas nasib, masa depan, dan kesejahteraan rakyat. Upaya pemberdayaan dapat dilakukan oleh masyarakat sendiri. Pemberdayaan dari dalam masyarakat biasanya diprakarsai oleh para pemangku kepentingan seperti kepala desa, lurah, ketua RT, ketua RW, dan lain-lain. Terjadinya konversi lahan sawah menjadi kebun, perumahan, dan kawasan industri menimbulkan pertanyaan apakah budidaya padi sawah kurang menguntungkan bagi petani?. Belum lagi ancaman banjir dan kemarau yang kerap menyebabkan gagal panen, serta rusaknya saluran irigasi yang membutuhkan perbaikan. Selain itu, berbagai hambatan klasik usahatani padi sawah yang dihadapi petani diantaranya: Kemandirian meningkatkan efisiensi penggunaan input, Kemandirian dalam pengadaan input pertanian, kemandirian dalam pemasaran hasil dan berkelanjutan

Kesimpulan dari penelitian menunjukkan bahwa pemberdayaan masyarakat petani dalam meningkatkan kesejahteraan hidup yang selama ini dilakukan oleh Pemerintah Kecamatan Compreng belum berjalan maksimal. Saran yang perlu dilakukan adalah keberadaan Gabungan Kelompok Tani perlu ditingkatkan dan dikembangkan, partisipasi masyarakat petani yang harus sejalan dengan Pemerintah dalam artian Pemerintah dan Masyarakat sebagai objek pemberdayaan harus berjalan 
selaras bersamaan, Pemberdayaan yang berkelanjutan di lingkungan petani masyarakat Kecamatan Compreng.

\section{Pendahuluan}

Salah satu tugas utama dibentunya suatu Negara adalah meningkatkan kesejahteraan warga Negara. Kesejahteraan dapat diwujudkan melalui pembangunan dan pemberdayaan. Pembangunan tidak hanya mengejar pertumbuhan namun juga perlu memperhatikan aspek lingkungan sehingga tidak terjadi ekploitasi terhadap sumber daya alam yang dimiliki untuk meweujudkan kesejahteraan. Revolusi hijau merupakan salah satu bentuk pembangunan yang mengeksploitasi lahan pertanian. Dampak positif yang dirasakan adalah mampu melakukan swasembada pangan pada tahun 1984.

Dalam rangka mewujudkan Indonesia yang berdaulat, mandiri, dan berkepribadian berlandaskan gotong-royong yang sesuai dengan visi kabupaten subang diperlukan kajian mengenai pemberdayaan masyarakat di wilayah perdesaan pertanian. Salah satu pemberdayaan masyarakat adalah pemberdayaan terhadap masyarakat petani khususnya di wilayah-wilayah perdesaan yang memiliki populasi yang cukup besar. Kemiskinan masih merupakan masalah besar kabupaten subang terutama di wilayah perdesaan yang mayoritasnya adalah petani sawah. di Indonesia sendiri, meskipun tingkat kemiskinan sudah menurun namun penurunan tersebut belum mencapai target RPJM. Kemiskinan di Indonesia lebih terpusat di daerah pedesaan yang identik dengan petani.

Sumawinata (2004) menyebutkan bahwa lebih 80 persen rakyat Indonesia hidup di pedesaan, dimana hanya sekitar 10-15 persen yang merupakan golongan menengahatas. Bahkan dari sekitar 80 persen sisanya merupakan rakyat desa serba kekurangan, 40 persennya tergolong rakyat desa sangat miskin dan miskin, serta proporsi terbesar penduduk miskin adalah penduduk yang sumber penghasilannya dari pertanian (petani). Menurut Sunyoto Usman ( $2004: 39$ ) bahwa salah satu strategi penting dalam pembangunan adalah pentingnya pemberdayaan pada masyarakat. Pemberdayaan pada masyarakat adalah satu kekuatan yang sangat vital. Kekuatan yang dimaksud dapat dilihat dari aspek fisik, material, aspek ekonomi dan pendapatan, aspek kelembagaan (tumbuhnya kekua-tan individu dalam bentuk wadah/kelompok), kekuatan kerjasama, kekuatan intelektual dan kekuatan komitmen bersama untuk mematuhi dan menerapkan prinsip-prinsip pemberdayaan. 
Arti pentingnya pemberdayaan masyarakat adalah menciptakan kemandirian, agar masyarakat mampu berbuat, memahami serta mengaplikasikan dalam berbagai kegiatan pembangunan.Pemberdayaan dianggap penting dalam meningkatkan taraf hidup, tingkat kesejahteraan, serta pengembangan ekonomi masyarakat. Kemiskinan dapat meningkat dimana kejadian rawan pangan khususnya pada masyarakat petani diprediksi akan bertambah dengan adanya perubahan iklim (global warming). Global warming berdampak pada perubahan pola distribusi ketersediaan air secara spatial dan temporal, dan menyebabkan peluang kekeringan di musim kemarau meningkat dan peluang banjir di musim hujan akan meningkat pula. Kondisi ini menyebabkan terganggunya sistem produksi pangan seperti awal tanam mundur, intensitas tanam berkurang, intensitas organisme pengganggu tanaman akan meningkat, dan yang lebih parah adalah gagal panen karena terendamnya sawah akibat kebanjiran.

Keberadaan Paguyuban Petani Kecamatan Compreng GAPOKTAN (Gabungan Kelompok Tani) dilatarbelakangi oleh keinginan yang kuat untuk membebaskan diri dari kemiskinan. Kemiskinan petani tersebut menandai betapa lemah posisi tawar petani terhadap struktur politik, ekonomi, sosial, dan budaya yang ada. Pergulatan sejarah di negeri ini telah menempatkan petani dalam posisi marginal sedangkan yang harusnya petani, sebagai penyangga pilar kehidupan, tidak boleh terabaikan. Kebijakan agrikultur revolusi hijau menyebabkan semakin tingginya tingkat ketergantungan petani terhadap sektor di luar pertanian. Sedangkan dampak rusaknya lingkungan yang diakibatkan oleh kebijakan tersebut harus dibayar mahal. Kondisi yang tidak menguntungkan petani ini diperparah oleh minimnya kemampuan petani mengorganisir diri dalam mengartikulasikan hak-haknya. Pada akhirnya petani yang lemah secara ekonomi akan terus termarginalkan dan ditindas oleh pemodal dan sistem pasar. Berdasarkan uraian diatas, dirasa perlu meningkatkan Pemberdayaan Masyarakat Petani Dalam Meningkatkan Kesejahteraan Hidup.

\section{Tinjauan Pustaka}

\section{Pengertian Pemberdayaan}

Istilah -pemberdayaan ce diambil dari Bahasa Inggris -empowerment, yang berasal dari kata dasar - power $r^{\text {ee }}$ berarti kekuatan atau -daya ${ }^{e e}$ dalam Bahasa Indonesia. Empowerment dalam Bahasa Inggeris diterjemahkan sebagai pemberdayaan dalam Bahasa Indonesia. Maka definisi pemberdayaan dirumuskan sebagai upaya yang 
bertujuan untuk meningkatkan kekuatan/daya (power) pihak-pihak yang tidak atau kurang berdaya.

Pemberdayaan juga bermakna sebagai upaya distribusi-ulang (redistribusi) kekuatan/daya (power) dari pihak yang memilikinya kepada pihak yang tidak atau kurang memilikinya. Karena itu, pemberdayaan selalu mengandung pengertian :

a. Pengurangan atau pemindahan daya (power) atau upaya melakukan disempowerment / less empowering pihak-pihak yang memiliki kekuatan/ daya (power).

b. Penyerahan/penambahan daya (power) kepada pihak-pihak yang diberdayakan (empowerment).

Konsep pemberdayaan dapat dikatakan merupakan jawaban atas realitas ketidakberdayaan (disempowerment). Mereka yang tidak berdaya jelas adalah pihak yang tidak memiliki daya atau kehilangan daya. Mereka yang tidak berdaya adalah mereka yang kehilangan kekuatannya. Secara lebih lengkap suatu pemberdayaan memiliki maksud untuk :

1. Pemberdayaan bermakna kedalam, kepada masyarakat berarti suatu usaha untuk mentranspormasikan kesadaran rakyat sekaligus mendekatkan masyarakat dengan akses untuk perbaikan kehidupan mereka.

2. Pemberdayaan bermakna keluar sebagai upaya untuk menggerakkan perubahan kebijakan-kebijakan yang selama ini nyata-nyata merugikan masyarakat. Pemberdayaan dalam segi ini bermakna sebagai pengendali yang berbasis pada upaya memperlebar ruang partisipasi rakyat (Pambudi, 2003:54-58).

Sulistiyani (2004: 7) menjelaskan bahwa -Secara etimologis Pemberdayaan berasal dari kata dasar daya yang berarti kekuatan atau kemampuan . Bertolak dari pengertian tersebut, maka pemberdayaan dimaknai sebagai proses untuk memperoleh daya, kekuatan atau kemampuan, dan atau pemberian daya, kekuatan atau kemampuan dari pihak yang memiliki daya kepada pihak yang kurang atau belum berdaya. Pemberdayaan memerlukan keterlibatan masyarakat secara aktif. dalam konteks pemberdayaan, masyarakat harus diberdayakan untuk merumuskannya sendiri melalui sebuah proses pembangunan konsensus diantara berbagai individu dan kelompok sosial yang memiliki kepentingan dan menanggung resiko langsung (stakeholders) akibat adanya proses atau intervensi pembangunan, baik pembangunan ekonomi, sosial maupun lingkungan fisik. 


\section{Pemberdayaan Masyarakat}

Pemberdayaan masyarakat biasa dipahami atau diartikan sebagai proses mengembangkan, memandirikan, menswadayakan, memperkuat posisi tawar menawar masyarakat lapisan bawah terhadap kekuatan-kekuatan penekan di segala bidang dan sektor kehidupan. ada pula pihak lain yang menegaskan bahwa pemberdayaan adalah proses memfasilitasi warga masyarakat secara bersama-sama pada sebuah kepentingan bersama atau urusan yang secara kolektif dapat mengidentifikasi sasaran, mengumpulkan sumber daya, mengerahkan suatu kampanye aksi dan oleh karena itu membantu menyusun kembali kekuatan dalam komunitas.

Hal ini juga dikuatkan oleh pendapat Sumodingrat (2009:7), yang mengemukakan bahwa masyarakat adalah makhluk hidup yang memiliki relasi sosial maupun ekonomi, maka pemberdayaan sosial merupakan suatu upaya untuk membangun semangat hidup secara mandiri dikalangan masyarakat untuk memenuhi kebutuhan hidup masing-masing secara bersama-sama.

Jim Ife (1995:56) mengungkapkan bahwa pemberdayaan ditujukan untuk meningkatkan kekuasaan (power) dari kelompok masyarakat yang kurang beruntung (disadvantaged). Payne dalam Adi (2003:54) mengemukakan bahwa: -Proses pemberdayaan pada intinya ditujukan guna membantu klien memperoleh daya untuk mengambil keputusan dan menentukan tindakan yang akan dia lakukan yang terkait dengan diri mereka, termasuk mengurangi efek hambatan pribadi dan sosial dalam melakukan tindakan. Hal ini dilakukan melalui peningkatan kemampuan dan rasa percaya diri untuk menggunakan daya yang dia miliki, antara lain melalui transfer daya dari lingkungannya .

Berdasarkan definisi-definisi tersebut diatas, pemberdayaan masyarakat adalah suatu proses untuk meningkatkan kemampuan atau kapasitas masyarakat dalam memamfaatkan sumber daya yang dimiliki, baik itu sumber daya manusia (SDM) maupun sumber daya alam (SDA) yang tersedia dilingkungannya agar dapat meningkatkan kesejahteraan hidupnya. Namun upaya yang dilakukan tidak hanya sebatas untuk meningkatkan kemampuan atau kapasitas dari masyarakat untuk memenuhi kebutuhan hidupnya, tetapi juga untuk membangun jiwa kemandirian masyarakat agar berkembang dan mempunyai motivasi yang kuat dalam berpartisipasi dalam proses pemberdayaan. Masyarakat dalam hal ini menjadi pelaku atau pusat proses pemberdayaan. 


\section{a. Prinsip-Prinsip Pemberdayaan Masyarakat}

Terdapat empat prinsip yang sering digunakan untuk suksesnya program pemberdayaan, yaitu prinsip kesetaraan, partisipasi, keswadayaan atau kemandirian, dan berkelanjutan. Adapun lebih jelasnya adalah sebagai berikut:

1. Prinsip Kesetaraan

Prinsip utama yang harus dipegang dalam proses pemberdayaan masyarakat adalah adanya kesetaraan atau kesejajaran kedudukan antara masyarakat dengan lembaga yang melakukan program-program pemberdayaan masyarakat, baik laki-laki maupun perempuan. Dinamika yang dibangun adalah hubungan kesetaraan dengan mengembangkan mekanisme berbagai pengetahuan, pengalaman, serta keahlian satu sama lain. Masing-masing saling mengakui kelebihan dan kekurangan, sehingga terjadi proses saling belajar.

\section{Partisipasi}

Program pemberdayaan yang dapat menstimulasi kemandirian masyarakat adalah program yang sifatnya partisipastif, direncanakan, dilaksanakan, diawasi, dan dievaluasi oleh masyarakat. Namun, untuk sampai pada tingkat tersebut perlu waktu dan proses pendampingan yang melibatkan pendamping yang berkomitmen tinggi terhadap pemberdayaan masyarakat.

\section{Keswadayaan atau kemandirian}

Prinsip keswadayaan adalah menghargai dan mengedepankan kemampuan masyarakat daripada bantuan pihak lain. Konsep ini tidak memandang orang miskin sebagai objek yang tidak berkemampuan (the have not), melainkan sebagai subjek yang memiliki kemampuan sedikit (the have little). Mereka memiliki kemampuan untuk menabung, pengetahuan yang mendalam tentang kendala-kendala usahanya, mengetahui kondisi lingkungannya, memiliki tenaga kerja dan kemauan, serta memiliki norma-norma bermasyarakat yang sudah lama dipatuhi. Semua itu harus digali dan dijadikan modal dasar bagi proses pemberdayaan. Bantuan dari orang lain yang bersifat materiil harus dipandang sebagai penunjang, sehingga pemberian bantuan tidak justru melemahkan tingkat keswadayaannya. Prinsip -mulailah dari apa yang mereka punya , menjadi panduan untuk mengembangkan keberdayaan masyarakat. Sementara bantuan teknis harus secara terencana mengarah pada peningkatan kapasitas, sehingga pada akhirnya pengelolaannya dapat dialihkan kepada masyarakat sendiri yang telah mampu mengorganisir diri untuk menyelesaikan masalah yang dihadapi.

\section{Berkelanjutan}


Program pemberdayaan perlu dirancang untuk berkelanjutan, sekalipun pada awalnya peran pendamping lebih dominan dibanding masyarakat sendiri. Tapi secara perlahan dan pasti, peran pendamping akan makin berkurang, bahkan akhirnya dihapus, karena masyarakat sudah mampu mengelola kegiatannya sendiri.

\section{b. Tujuan Pemberdayaan Masyarakat}

Tujuan pemberdayaan adalah memperkuat kekuasaan masyarakat khususnya kelompok lemah yang tidak berdaya, baik karena kondisi internal (misalnya persepsi mereka sendiri) maupun karena kondisi eksternal (misalnya ditindas oleh struktur sosial yang tidak adil). Guna memahami tentang pemberdayaan perlu diketahui konsep mengenai kelompok lemah dengan ketidakberdayaan yang dialaminya. Beberapa kelompok yang dapat dikategorikan sebagai kelompok lemah atau tidak berdaya meliputi:

1. Kelompok lemah secara struktural, baik lemah secara kelas, gender maupun etnis.

2. Kelompok lemah khusus, seperti manula, anak-anak dan remaja, penyandang cacat, gay dan lesbian, masyarakat terasing.

3. Kelompok lemah secara personal, yakni mereka yang mengalami masalah pribadi dan atau keluarga.

\section{Metode Penelitian}

Penelitian ini menggunakan pendekatan penelitian kualitatif yaitu penelitian yang dapat diartikan sebagai prosedur pemecahan masalah yang diselidiki dengan menggambarkan, melukiskan keadaan subyek atau obyek penelitian pada saat sekarang berdasarkan fakta-fakta yang tampak atau sebagaimana adanya.

Teknik pengumpulan data, yaitu: observasi, wawancara, dan dokumentasi. Teknik keabsaan data yang digunakan dalam penelitian ini yaitu triangulasi sumber dan triangulasi metode. Teknik analisis data yang digunakan dalam penelitian ini yaitu teknik analisis data kualitatif, yaitu pengumpulan data, reduksi data, penyajian data, dan penarikan kesimpulan/verifikasi. 


\section{Pembahasan}

Peningkatan ketahanan pangan merupakan salah satu tujuan pembangunan nasional. Dari sisi produksi, peningkatan ketahanan pangan tersebut diupayakan melalui peningkatan produksi beras terutama yang dihasilkan dari lahan sawah. Berbagai hasil penelitian mengungkapkan bahwa laju pertumbuhan produksi beras akhir akhir ini justru semakin lambat yang berdampak pada menurunnya tingkat kesejahteraan hidup petani.

Pada kondisi dimana produktivitas usaha tani padi semakin sulit ditingkatkan, peningkatan luas panen padi merupakan upaya yang terpaksa dilakukan untuk meningkatkan kesejahteraan hidup petani di Kecamatan Compreng. Alih fungsi lahan sudah sejak lama menjadi masalah, khususnya di Jawa Barat Kabupaten Subang Kecamatan Compreng yang berdamoak langsung pada kehidupan petani, dimana para petani menjadi kehilangan sumber penghasilan dari petani sawah. Mayoritas masyrakat yang berprofesi sebagai buruh tani lambat laun sudah mulai ditinggalkan karena berubahnya lahan lahan pertanian menjadi pemukiman rumah penduduk.

\section{Prinsip Kesetaraan}

Prinsip utama yang harus dipegang dalam proses pemberdayaan masyarakat adalah adanya kesetaraan atau kesejajaran kedudukan antara masyarakat dengan lembaga yang melakukan program-program pemberdayaan masyarakat, baik laki-laki maupun perempuan. Globalisasi menimbulkan berbagai dampak dalam kehidupan masyarakat. Salah satu dampak globalisasi berupa ketimpangan sosial. Pemasalahan ketimpangan sosial muncul akibat adanya perbedaan mencolok dalam kehidupan satu masyarakat dibandingkan masyarakat lain.

Dalam konteks globalisasi permasalahan ketimpangan sosial tampak dalam hubungan negara-negara dengan ekonomi kuat dan negara-negara dengan ekonomi lemah. Untuk mengatasi kondisi tersebut, diperlukan pemberdayaan komunitas. Melalui pemberdayaan komunitas akan tumbuh kemandirian masyarakat untuk berani menghadapi setiap tantangan, dampak, ataupun peluang yang muncul ditengah pengaruh globalisasi.

Keberadaan GAPOKTAN di Kecamatan Compreng sangat membantu sekali untuk keberlangsungan kesejahteraan hidup para petani oleh karenanya pemerintah harus mampu mengelola dengan baik keberadaan GAPOKTAN. Pemerintah memiliki peran penting dalam melakukan pemberdayaan masyarakat karena bertanggung jawab 
atas nasib, masa depan, dan kesejahteraan rakyat. Upaya pemberdayaan dapat dilakukan oleh masyarakat sendiri. Pemberdayaan dari dalam masyarakat biasanya diprakarsai oleh para pemangku kepentingan seperti kepala desa, lurah, ketua RT, ketua RW, dan lain-lain.

Keberadaan kelompok tani sendiri merupakan inisiatif dari masyarakat yang bertujuan untuk meningkatkan pertanian di Kecamatan Compreng dengan tujuan utamanya adalah meningkatkan kesejahteraan hidup para petani. Kelompok tani sendiri adalah kumpulan petani/peternak/pekebun yang dibentuk atas dasar kesamaan kepentingan, kesamaan kondisi lingkungan (sosial, ekonomi, sumberdaya) dan keakraban untuk meningkatkan dan mengembangkan usaha anggota. Gabungan Kelompok Tani sendiri merupakan kumpulan beberapa kelompok tani yang bergabung dan bekerjasama untuk meningkatkan skala ekonomi dan efisiensi usaha. Kelompok tani pada dasarnya adalah organisasi non formal diperdesaan yang ditumbuhkembangkan dari, oleh dan untuk petani dengan ciri -ciri sebagai berikut :

a. Saling kenal, akrab dan saling percaya diantara sesama anggota.

b. Mempunyai pandangan dan kepentingan yang sama dalam berusaha tani.

c. Memiliki kesaamaan dalam tradisi dan atau pemukiman, hamparan usaha, jenis usaha, status ekonomi maupun sosial, bahasa, pendidikan dan ekologi.

d. Ada pembagian tugas dan tanggungjawab sesama anggota berdasarkan kesepakatan bersama.

Selain memiliki ciri tersebut, juga memiliki beberapa unsur pengikat yaitu :

a. Adanya kepentingan yang sama diantara para anggotanya.

b. Adanya kawasan usaha tani yang menjadi tanggungjawab bersama diantara para anggota.

c. Adanya kader tani yang berdedikasi untuk menggerakkan para petani dan kepemimpinannya diterima oleh sesama petani lainnya.

d. Adanya kegiatan yang dapat dirasakan manfaatnya oleh sekurang-kurangnya sebagian besar anggotanya.

e. Adanya dorongan atau motivasi dari tokoh masyarakat setempat untuk menunjang program yang telah ditentukan.

\section{Partisipasi}

Program pemberdayaan yang dapat menstimulasi kemandirian masyarakat adalah program yang sifatnya partisipastif, direncanakan, dilaksanakan, diawasi, dan dievaluasi oleh masyarakat. Namun, untuk sampai pada tingkat tersebut perlu waktu 
dan proses pendampingan yang melibatkan pendamping yang berkomitmen tinggi terhadap pemberdayaan masyarakat.

Permasalahan mendasar yang banyak dihadapi sebagian besar petani adalah kurangnya akses kepada sumber permodalan, pasar, dan teknologi serta organisasi tani yang masih lemah. Oleh karena itu, penanggulangan kemiskinan merupakan bagian dari pelaksanaan rencana pembangunan jangka panjang dan kesepakatan global untuk mencapai tujuan pembangunan ekonomi. Kementerian

Pertanian mulai tahun 2008 telah melaksanakan Program Pengembangan Usaha Agribisnis Pedesaan (PUAP) di bawah koordinasi Program Nasional Pemberdayaan Masyarakat Mandiri (PNPM Mandiri) dan termasuk dalam kelompok program pemberdayaan masyarakat. Program PUAP merupakan salah satu program Kementerian Pertanian untuk meningkatkan kesejahteraan petani. Program ini merupakan bentuk fasilitas bantuan modal usaha untuk petani anggota, baik petani penggarap, buruh tani maupun rumah tangga tani yang nantinya akan dikoordinasikan oleh Gabungan Kelompok Tani (Gapoktan).

Gapoktan merupakan kelembagaan di tingkat petani yang melaksanakan program PUAP untuk penyaluran bantuan modal usaha bagi anggota. Guna mencapai hasil yang maksimal dalam pelaksanaan PUAP, dalam prosesnya Gapoktan didampingi oleh tenaga Penyuluh Pendamping dan Penyelia Mitra Tani (PMT). Gapoktan PUAP diharapkan dapat menjadi kelembagaan ekonomi yang dimiliki dan dikelola petani. Guna mencapai tujuan PUAP yaitu mengurangi tingkat kemiskinan dan pengangguran di pedesaan, PUAP dilaksanakan secara terintegrasi dengan kegiatan kementerian pertanian maupun lembaga lain di bawah naungan Program PUAP (Menteri Pertanian Republik Indonesia, 2010).

Pengembangan masyarakat harus selalu berupaya untuk memaksimalkan partisipasi, dengan tujuan melibatkan masyarakat secara aktif terhadap prosesproses dan kegiatan masyarakat, serta untuk menciptakan kembali masa depan masyarakat dan individu. Dengan demikian, partisipasi merupakan suatu bagian penting dari pemberdayaan dan penumbuhan kesadaran. Semakin banyak orang yang berperan aktif dan semakin lengkap partisipasinya, semakin ideal kepemilikan dan proses masyarakat serta proses-proses inklusif yang akan diwujudkan (Ife dan Frank, 2008).

Partisipasi masyarakat didorong melalui proyek pembangunan bagi masyarakat desa yang dirancang sederhana dan mudah dikelola oleh masyarakat. Organisasi dan lembaga kemasyarakatan salah satu wadah yang mampu menggerakkan dan 
menyalurkan aspirasi masyarakat, peningkatan peranan masyarakat dalam pembangunan, sehingga masih dibutuhkan wadah untuk berpartisipasi di tingkat kelompok. Melalui wadah partisipasi tersebut anggota kelompok akan saling belajar melalui pendekatan learning by doing yang berarti belajar dengan melakukannya, menuju pada tujuan peningkatan kualitas hidup yang lebih baik, sehingga yang terjadi adalah adanya perubahan pengetahuan, keterampilan, dan sikap yang merupakan potensi untuk pembangunan (Van Den Ban dan Hawkins, 1999).

\section{Keswadayaan atau Kemandirian}

Prinsip keswadayaan adalah menghargai dan mengedepankan kemampuan masyarakat daripada bantuan pihak lain. Konsep ini tidak memandang orang miskin sebagai objek yang tidak berkemampuan (the have not), melainkan sebagai subjek yang memiliki kemampuan sedikit (the have little). Mereka memiliki kemampuan untuk menabung, pengetahuan yang mendalam tentang kendala-kendala usahanya, mengetahui kondisi lingkungannya, memiliki tenaga kerja dan kemauan, serta memiliki norma-norma bermasyarakat yang sudah lama dipatuhi.

Suplay beras di Indonesia sangat bergantung dari hasil produksi sawah rakyat. Untuk itu, petani padi sawah harus diposisikan sebagai pelaku utama pembangunan pertanian dan sangat menentukan mampu atau tidaknya Indonesia menjadi negara yang tangguh di bidang pangan. Kabupaten Subang Khususnya Kecamatan Compreng yang mayoritas lahannya adalah lahan Pertanian Sawah sebagai pelaku utama, agar dapat terus menyuplai beras, petani padi sawah harus sejahtera. Kesejahteraan yang dimaksud, adalah kondisi dimana hasil usaha tani padi sawah dapat memenuhi kebutuhan pokok petani termasuk pendidikan dan kesehatan, bukan terpenuhi dari hasil usaha lain. Dengan demikian, usahatani padi sawah harus berorientasi bisnis yang menguntungkan.

Terjadinya konversi lahan sawah menjadi kebun, perumahan, dan kawasan industri menimbulkan pertanyaan apakah budidaya padi sawah kurang menguntungkan bagi petani?. Belum lagi ancaman banjir dan kemarau yang kerap menyebabkan gagal panen, serta rusaknya saluran irigasi yang membutuhkan perbaikan. Selain itu, berbagai hambatan klasik usahatani padi sawah yang dihadapi petani diantaranya:

a. Belum efisiennya penggunaan input.

b. Ketergantungan terhadap input pertanian yang bersifat instan (benih dan pupuk an organik). 
c. Lemahnya kemampuan pemasaran hasil, merupakan faktor-faktor pembataspeningkatan kesejahteraan petani padi sawah sekaligus hambatan pencapaian swasembada beras berkelanjutan.

Mencermati berbagai faktor pembatas pencapaian swasembada beras berkelanjutan di muka, dibutuhkan upaya strategis yang mudah dilaksanakan. Masalah konversi lahan dan perbaikan saluran irigasi bagian dari komitmen pemerintah untuk menetapkan kebijakan dan penganggaran pendanaan perbaikan infrastruktur pertanian. Namun, mengingat petani padi sawah adalah pelaku utama, maka upaya strategis yang paling substansial yakni meningkatkan kemandirian petani agar dapat mengatasi permasalahan klasik di muka.

\section{Kemandirian meningkatkan efisiensi penggunaan input}

Efisiensi usaha tercapai ketika usaha dijalankan dengan penggunaan tenaga, waktu, dan biaya sesuai kebutuhan. Di Indonesia, efisiensi penggunaan input budidaya padi sawah terkendala sempitnya luas lahan sawah rata-rata petani (petani gurem) dan aktivitas budidaya padi masih dilakukan perorangan. Berbeda dengan Indonesia, kepemilikan lahan rata-rata petani di negara maju seperti Amerika Serikat (200 hektar) dan jepang (20 hektar) menyebabkan peningkatan efisiensi penggunaan input lebih mudah dicapai (Pakpahan, 2008). Semakin luas lahan usahatani, penerapan mekanisasi pertanian terutama dalam pengolahan lahan dan panen akan lebih efisien karena dapat dilakukan lebih cepat. Dengan keseragaman waktu tanam, maka penentuan sistem tanam, pengaturan pola tanam, penanganan panen dan pasca panen, serta pemasaran hasil dapat dilakukan dengan manajemen yang lebih baik. Begitu pula efisiensi biaya dalam pengadaan sarana produksi (saprodi) seperti benih dan pupuk akan semakin tinggi seiring tingginya volume input yang diadakan.

Mengingat rata-rata petani di Indonesia berlahan sempit $(<0,35$ hektar), maka peningkatkan kemandirian petani guna memaksimalkan efisiensi usahatani padi sawah diperlukan kebersamaan usaha. Petani padi sawah yang rata-rata berlahan sempit perlu diorganisir agar mau melakukan kegiatan usahatani dalam satu manajemen usaha terpadu berbentuk Badan Usaha Milik Petani.

\section{Kemandirian dalam pengadaan input pertanian}

Ketersediaan input pertanian secara lokal merupakan salah satu syarat wajib pembangunan pertanian (Mosher, 1966 dalam Mubyarto, 1989). Benih dan pupuk 
merupakan input pertanian pokok dalam budidaya padi. Semakin unggul benih serta semakin berimbang pupuk yang digunakan, produksi yang dicapai akan semakin tinggi pula. Namun, kenyataannya keberadaan benih unggul dan pupuk an organik tidak diproduksi secara lokal, sehingga ketersediaannya bergantung pada suplay dari

produsen. Seiring waktu, ketersediaan benih unggul lokal dan pemanfaatan pupuk organik semakin berkurang. Kini petani sangat bergantung pada benih unggul dan pupuk an organik produksi perusahaan penyedia sarana pertanian.

Ketersediaan benih unggul secara lokal merupakan upaya yang mulai ditempuh dewasa ini dengan mendorong petani menjadi penangkar benih (program 1000 desa mandiri benih). Upaya ini lebih berorientasi pemberdayaan petani dan mengedepankan aspek kemandirian. Dengan pola ini, benih unggul dapat tersedia secara lokal, sehingga murah dan mudah didapat.

Selanjutnya, upaya meningkatkan kemandirian petani dalam memenuhi kebutuhan pupuk dapat ditempuh melalui penggiatan integrasi ternak dengan tanaman. Adanya integrasi ternak dan tanaman merupakan pola usahatani yang ideal dikembangkan guna meningkatkan kemandirian petani agar terlepas dari ketergantungan terhadap pupuk an organik. Dengan beternak, petani berpeluang memperoleh kotoran padat dan cair sebagai bahan baku pembuatan pupuk organik.

\section{Kemandirian dalam pemasaran hasil}

Pemasaran hasil adalah faktor terakhir penentu pendapatan petani dalam berusahatani. Tingginya produksi saja tidak menjamin tingginya pendapatan jika petani tidak menguasai pemasaran hasil. Umumnya petani padi sawah di Indonesia memasarkan hasil secara perorangan yang menyebabkan lemahnya posisi tawar, sehingga harga ditentukan pihak pembeli. Dengan demikian, peningkatan kemandirian petani dalam pemasaran hasil hanya akan terjadi apabila petani mau bersatu memasarkan hasil bersama (kolektif).

Merujuk kepada permasalahan di muka, kemandirian petani dapat terjadi apabila petani telah mampu meningkatkan efisiensi penggunaan input melalui kebersamaan usaha, mampu menyediakan input pertanian secara lokal (khususnya benih dan pupuk), serta mampu memasarkan hasil bersama-sama. Salah satu upaya yang mungkin dilakukan untuk meningkatkan kemandirian petani padi sawah yakni mendorong petani agar mau melakukan kegiatan budidaya dalam satu manajemen usaha yang terpadu, terorganisir, dan terkontrol dengan baik. 
Sudah adanya kelembagaan tani seperti Gabungan Kelompok Tani (Gapoktan) merupakan modal sosial yang harus diberdayakan. Meningkatkan kemampuan Gapoktan untuk lebih berdaya dalam menjalankan fungsi-fungsi organisasinya,dibutuhkankegotongroyongan permodalan yang lebih kuat. Gapoktan harus di dorong agar mampu berkembang menjadi badan usaha yang mampu bergerak pada semua sub sektor agribisnis, sehingga tidak lagi berperan sebagai penyuplay produksi pertanian primer saja, tetapi juga perlu direkayasa agar mampu mengakses permodalan, menyediakan sarana produksi, serta mampu memasarkan hasil produksi secara bersama.

\section{Berkelanjutan}

Program pemberdayaan perlu dirancang untuk berkelanjutan, sekalipun pada awalnya peran pendamping lebih dominan dibanding masyarakat sendiri. Tapi secara perlahan dan pasti, peran pendamping akan makin berkurang, bahkan akhirnya dihapus, karena masyarakat sudah mampu mengelola kegiatannya sendiri.

Sesuai amanat pembukaan UUD 1945 disebutkan bahwa tujuan negera adalah melindungi segenap bangsa Indonesia dan seluruh tumpah darah Indonesia dan untuk memajukan kesejaheraan umum, mencerdaskan kehidupan bangsa dan ikut melaksanakan ketertiban dunia berdasarkan kemerdekaan, perdamaian abadi dan keadilan sosial. Oleh karena itu perlindungan segenap bangsa dan peningkatan kesejahteraan umum merupakan tanggung jawab Negara untuk mewujudkannnya. Salah satu bentuk perlindungan tersebut adalah terjaminnya hak atas pangan bagi segenap rakyat yang merupakan hak asasi manusia yang sangat mendasar sehingga menjadi tanggung jawab Negara untuk memenuhinya. Untuk membangun ketahanan pangan, kemandirian pangan menuju kedaulatan pangan, perlu diupayakan melalui pelaksanaan pembangunan berkelanjutan.

Ditengah besarnya tanggung jawab pemerintah untuk mewujudkan ketahanan pangan, pembangunan pertanian menghadapi permasalahan dan tantangan yang sangat besar terutama tingginya alih fungsi lahan pertanian ke non pertanian sebagai akibat pertambahan penduduk. Dalam rangka pengendalian alih fungsi lahan pertanian pangan, pemerintah telah menetapkan Undang-Undang Nomor 41 Tahun 2009 tentang Perlindungan Lahan Pertanian Pangan Berkelanjutan. Dalam UU Nomor 41/2009 tersebut dengan jelas disebutkan bahwa Lahan Pertanian Pangan Berkelanjutan (LP2B) adalah bidang lahan pertanian yang ditetapkan untuk dilindungi dan dikembangkan 
secara konsistem guna menghasilkan pangan pokok bagi kemandirian, ketahanan dan kedaulatan pangan nasional.

\section{Simpulan Saran}

Pembahasan yang sudah di sajikan dapat ditarik kesimpulan bahwa pemberdayaan masyarakat petani dalam meningkatkan kesejahteraan hidup yang selama ini dilakukan oleh Pemerintah Kecamatan Compreng belum berjalan maksimal.

1. Keberadaan Gabungan Kelompok Tani perlu ditingkatkan dan dikembangkan.

2. Partisipasi masyarakat petani yang harus sejalan dengan Pemerintah dalam artian Pemerintah dan Masyarakat sebagai objek pemberdayaan harus berjalan selaras bersamaan.

3. Keswadayaan atau Kemandirian Petani dalam mengelola lahan pertanian harus mandiri dan ditopang oleh peran aktif dalam memberi solsusi dari setiap permasalhan yang dihadapi oleh petani.

4. Pemberdayaan yang berkelanjutan di lingkungan petani masyarakat Kecamatan Compreng.

\section{Daftar Pustaka}

Adi, Isbandi Rukminto. 2002. Pemikiran- pemikiran dalam Pembangunan Kesejahteraan Sosial Pemberdayaan Masyarakat. Jakarta: FE Universitas Indonesia

Adiwilaga, 1992, Pembangunan Pertanian dan permasalahannya, PT Pradnya Paramita Jakarta.

Ahmad shukri Mohd-Nain dan Rosman Md Yusuf, 2003, Pemberdayaan Masyarakat Petani, PT Fokus Harapan Jakarta.

Anwas, Oos M. 2013. Pemberdayaan Masyarakat di Era Global. Bandung, Alfabeta.

Bayu Krisnamurthi 2008, Dinamika Kelom-pok Tani dalam mengatasi kemiskinan petani, Fokus Media Jakarta.

Buku Materi Paguyuban Petani Al-Barokah.

Creswell W. John. 2012 Research Design; pemdekatan kualitatif, kuantitatif dan Mixed. Yogyakarta, Pustaka Pelajar.

Mardikanto, Totok dan Poerwoko Soebiato.2013 Pemberdayaan Masyarakat Dalam Presektif Kebijakan Publik. Bandung, Alfabeta.

Moloeng, Lexy J. 2007. Metodologi Penelitian Kualitatif. Bandung: PT Remaja Rosdakarya 
Mulaya, Dedy. 2003. MetodePenelitian Kualitatif. Bandung: PT Remaja Rosdakarya Offset

Pakpahan, A. 2008. Badan Usaha Milik Petani sebagai Sarana Gotongroyong Usaha untuk Kemajuan Petani. www/apps/scribd/tmp/scratch7/10 267034 